\title{
The Study of Madness in Surfacing: Psychological trauma, Alienation and Schizophrenia
}

\author{
Esma Biroğlu \\ Department of English Language and Literature \\ Istanbul Aydın University \\ Istanbul-Turkey
}

\begin{abstract}
This study critically examines the depiction of madness in surfacing which is written in 1972 by the Canadian writer Margaret Atwood. The first part of the study traces what madness is, the history of madness and why it emerges in life. The second part offers a representation of madness of the unnamed narrator-protagonist in relation to her abortion and her realization of her own complicity in the patriarchal oppression of the women and nature. A light is also shed on the other causes that lie behind the narrator's mental disorder, like betrayal of her former boy friend, oppression of the society and alienation. The last part of this study examines the narrator's self-discovery journey which is full of risks after secluding herself on her native village in Quebec where she spent her childhood with her family.
\end{abstract}

Keywords: madness, victim, abortion, nature, self-discovery.

\section{Introduction}

\section{The Definition and History of Madness}

Giving a specific description of madness is hard. Throughout history, madness has been defined in various ways. Some certain symptoms of madness went parallel to the characteristics of each period of history and its description depended on the lenses which were used. Through the perspective of religion, it has been used for persecution; through the views of politics, it has been used for designating discrimination and oppression; through terms of medicine, it has been a state of mental illness and aesthetically it has been considered as an expression of the self and the society(Feder xii). Thus, sanity and normality cannot be separated from the culture and norms of the society.

Madness is not new to contemporary western culture. It traces back to ancient times. Many representations and narrative constructions of madness can be found in ancient mythology. Madness not only was seen as a disease or disorder of mind but also it was considered as a punishment of a god or goddess subjected to people who disobeyed the supernatural powers.

For many centuries, the madwomen were treated as animals and "violent mad women were chained by the ankles to the walls of longs gallery"(Foucault 71).The situation of the mad women was not different in the Victorians era. A mad woman was the woman who does not behave according to what is expected from her gender. Madness is attributed to women who wanted to be independent, to have different attitudes in their lives, to behave in a socalled masculine way, to have no interest in housework, not to marry or raise children, to live with a man without getting married or to marry but having no intention to be a mother. The woman who is not feminine enough is hidden, imprisoned or is sent to insane asylum which aims firstly to "reinforce conventional sex-role behaviour"'(Showalter 82).

In the beginning of the twentieth century the biological model was substituted by the psychological frame due to the influence of Freud. Properly speaking, many women were schizophrenic. Schizophrenia was not regarded as a mental malady but as a result of social oppression (Cooper $\mathrm{x}$ ) and a repercussion to unliveable situations (Showalter 221). Toward the mid of twentieth century actually there were many changes in the gender roles but madness still went on representing itself as a reaction to and revolution against the patriarchy suppression in the society. Today the combination of biological and psychological models is taken into account whenever madness is determined. 


\section{Madness in Surfacing}

Madness is "the flight of consciousness from painful encounters" (Hegel qtd. in Berthold-Bond 236). Generally speaking, madness stems from highly traumatic incidents when the mind blocks itself from further pain and damage. The following part will examine the elements of madness in Surfacing.

\section{Psychological Trauma}

According to the American Psychiatric Association trauma is brought about by the victim's response to many factors like abandonment, denial, violence, battering relationships and many others. The traumatized person loses their ability to cope with what is going around them and suffer from emotional agony. (3)

In Surfacing, psychological trauma can be found to a great extent. The protagonist has her traumatising events that dog her. This trauma plays out in the course of the novel. She expresses a disjointed line of thoughts. When she has flashbacks about her brother and how he was drowned in the lake before she was born, she claims that she remembers the incident clearly. Another incident which happens in a restaurant in her hometown is when her brother slid his hand down the waitress leg which makes us confused because again she recalls it evidently, despite the fact that she was not born yet.

While she is describing her wedding, we the readers became confused. She states that "at my wedding we filled our forms, name, age, birthplace, blood type. We had it in a post office, a J. P. did it" (Atwood 60). She remembers the exact scents of the people around her but it is strange because the scent is disturbing. Then she continues saying that bride and bridegroom go out and there are pigeons on the lawn near the fountain which have dolphins and a cherub. They walk through pigeons and confetti is blown up by people around them. The image is nice because the weather is sunny, there are birds and fountain and of course people who share their happiness. But then she expresses that the groom tells her "it is over" (61) and "feel better?"(61), "you are cold" (61). The bride-protagonist is surprised by his behaviour and tells herself that "he was talking to me as though I was an invalid, not a bride"(61). In fact, she is not the only one who gets confused but also we; the readers cannot get the right picture of the wedding. We can't help asking ourselves some questions like; is it a representation of a wedding or a funeral? Is it a state of happiness or sadness? Why is the bride sad and tired? Why are her legs shaking? Why is she cold? Why is he kissing her on the forehead not the mouth? Why are they going home not to a hotel to spend the honeymoon? There are many gaps and these gaps should be filled.

The protagonist always talks about her former husband and the child that she left in the city, therefore we understand that she has been married before and later she gets divorced. She tells us that her neighbour, Madame, will ask her about her baby. She will answer: "I'll tell her I left him in the city; that would be perfectly true, only it was a different city, he's better off with my husband, former husband" (13) and then she states how her family become upset with her marriage and divorce when she sends a letter to them telling about her last situation, and how she feels a sinner and stupid for leaving the child. For her, "stupidity is the same as evil if you judge by the results" (16).

Looking at the family albums, she notices that there are photos of her grandparents, parents, brother and her school photos but she sees no wedding pictures in the family album and then she remembers saying that "of course we hadn't taken any" (77).

In fact, we get persuaded that the protagonist has been married and has a baby. When her boy friend, Joe, makes a proposal of marriage, she does not want to marry again claiming that"I've been married before and it didn't work out. I had a baby too"... I do not want to go through this again. . . I've tried and failed; I'm inoculated, exempt, classified as wounded" (60).

However, sensing that something is going wrong and being "deprived of something" (7), she desires to know the truth about everything that occurs inside her:

I'm not sure when I began to suspect the truth, about myself and about them, what I was and what they were turning into. Part of it arrived swift as flags, as mushrooms, unfurling and sudden growth, but it was there in me, the evidence, only needing to be deciphered. (52)

Although she wants the facts, at the same time she fears them, therefore she tries to make herself busy by preparing meals, washing the dishes and weeding the garden in order to "preserve at least the signs of order, conceal [her] fear from others. . . Fear has a smell, as love does" (53). When her friends leave the island, she does not want to leave because "to go with them would have been running away, the truth is here" (123) and she wants 
to stay there alone. Although this is not a logical thing, still according to her, "there are no longer any rational points of view" (123).

Properly speaking, I think she is right in not confronting the facts that she has been through because they can damage her completely and she may not be able to bear them. This is exactly what happens to her when she sees the corpse of her dad; her painful memories come to the surface. She clarifies:

It was there but it wasn't a painting. It wasn't on the rock. It was below me, drifting towards me from the furthest level where there was no life, a dark oval trailing limbs. It was blurred but it had eyes, they were open, it was something I knew about, a dead thing, it was dead. (102)

Then, she remembers that she doesn't give birth to a baby. On the contrary, she has an abortion. Getting rid of the foetus leaves a deep scare in her psyche. She states:

I knew when it was, it was in a bottle curled up, staring out at me like a cat pickled; it had huge jelly eyes and fins instead of hands, fish gills, I couldn't let it out, it was dead already, it had drowned in air. It was there when I woke up, suspended in the air above me like a chalice, an evil grail and I thought, Whatever it is, part of myself or separate creature, I killed it. It wasn't a child but it could have been one, I didn't allow it. (103)

Accusing herself of being a killer just like Americans who destroy the nature, overfishing, overconsumeing, and killing the heron and hanging it on a tree, she gets worse. Recalling the incident, she starts to reveal the dualities that exist in her psyche and in the male-centred society. She states:

He hadn't come with me to the place where they did it; his own children, the real ones, were having a birthday party. . . But he came afterwards to collect me. It wasn't a wedding, there were no pigeons. (103)

Indeed, the unnamed narrator starts to remember the terrifying truth about her fake wedding and false memories. Although the ex-lover affirms that the aborted foetus was only an animal and not a child, his speech does not relieve her and she decides to leave him and not to go to her parents' house again. It is obvious that many women experience sadness, sorrow, and feelings of loss after they terminate their pregnancy, and "some experience clinically significant disorders, including depression and anxiety" (APA 3). The unnamed protagonist is under the process of mourning. Freud defines it as:

The reaction to the loss of a beloved person or an abstraction taking the place of the person ... Despite the fact that it produces severe deviations from normal behaviour. We rely on it being overcome after a certain period of time, and consider interfering with it to be pointless, or even damaging. (310-11)

Mourning the loss of the child totally wrecks her and leads her to emptiness, numbness and deadness. In spite of being young, she lacks the energy, does not feel like doing anything and resists moving on with her life due to her loss of the baby. What she used to do "was run to the end of the dock and jump, it was like a heart attack or lightning" (Atwood 50). But now she no longer has the nerve for jumping or anything else. She wonders "perhaps I am growing old; at last, can that be possible."( 51). In fact, she is not getting old but she feels like the old who have no strength or will to do anything because they think that they came to the end of the road of the life.

The narrator-protagonist cannot feel anything or she cannot love anymore. Thinking that one of her organ must be missing, therefore she cannot have feeling for Joe. She states that "I didn't love him, I was far away from him, it was as though I was seeing him through a smeared window or glossy paper" (114). Then, she tells herself and us that how she "came apart. the other half, the one locked away, was the only one that could live; [she]was the wrong half, detached, terminal.[she] was nothing but a head, or no, something minor like a severed thumb: numb(77). She has no reaction to anything because reacting to anything is an act of human beings. When Anna tells her that she must feel awful for refusing Joe's marriage proposal, she expresses:

I didn't feel awful: I realized I didn't feel much of anything. I hadn't for a long time. Perhaps, I'd been like that all my life, just as some babies are born deaf or without a sense of touch. (75)

When Joe explains to her that he likes the way she takes off her clothes and puts them on again as if she does not have emotion, she confesses to herself that she really does not have any feeling(16).

To sum up this section, in fact, the narrator suffers from psychological trauma which, according to Freud, can cause the disposition of one's memory and change a person's psychology, biology, and collective balance (Mollen 8). Additionally, the reason that lies behind the numbness of the narrator is that victims with traumatic experiences try to split themselves from the physical and emotional self-awareness in order to endure the disturbing situation and thus, move on life (Herman13).

60 


\section{Alienation}

Alienation is described as an umbrella which contains powerlessness, senselessness, pointlessness, lawlessness, social isolation and cultural and self-estrangement (Geyer qtd. in Marček 8). Literature has got three kinds of alienation. They are individual's alienation from himself or herself, alienation from the society and lastly one's alienation from God (Daronkolaee and Hojjat 202). Not having a name, staying on an island alone and thinking that people have the wrong God are the representations of all types of alienation in Surfacing.

Using a nameless narrator-protagonist, Atwood wants to shed light on women's fate even if these women are educated and independent earning their own livings. Except her, everyone in the novel has a name like Joe, David and Anna, even the characters who have small roles like Paul, Madame and Evans. Till the end of the story the protagonist does not get a name which can be a metaphor for the continuation of the suffering of the women even if they have love, job, company and security.

Broadly speaking, the most important reason for not giving a protagonist a name by Atwood is to use the nameless narrator as a metaphor for the situation of all women in the world who go through oppression. Since her story is about of all women with different races, ranks, education and status, we find ourselves absorbed in reading her suffer, reacting with her and wondering how she will end her trip of madness.

Truthfully, the nameless story-teller is like Mary Shelly's Frankenstein. The creature has been abandoned by his creator, victor, and also by the humanity. Lacking a name, not feeling secured, not being loved by anyone even by people whom he helps, having no aim or purpose in the life makes the creature as an outsider in the society. Just the case is with our nameless narrator of Surfacing who gets betrayed by her ex-lover and abandoned by her parents. Additionally, the oppression of the society on her as a woman contributes to her alienation. Evaluating the behaviour of men toward women, seeing their way of controlling women and perceiving their destruction of the nature, she finds men alienating and thus, she feels herself as an outcast in the world.

There are many reasons behind the protagonist's alienation, as I mentioned above, but the most disturbing experience that makes her alienated is the betrayal of her former lover. She illuminates that "he said he loved me, the magic word, it was supposed to make everything light up, I'll never trust that word again" (Atwood 30).

The narrator cannot believe how the man whom she loved and trusted betrayed her. He forced her to get rid of the baby because he already has his own real family. Desiring to lead his own life successfully and not to be affected by anything, he is ready to destroy anything that can have impact on his family or career at any price.

Moreover, the art professor did not stay in the hospital during the abortion because his real child has a birthday party. Leading a normal life, enjoying, singing songs and dancing in the party with his real family, he forces the narrator to kill the baby and not give it a chance to live. Thus, he compels the narrator to commit a "betrayal against life" (Alban 190). The former lover even does not understand the destruction that he causes to her instead he thinks that she should be grateful for him for arranging the abortion operation. She depicts:

In the car I didn't cry, I didn't want to look at him. "I know it is tough", he said, "but it's better this way.". . He'd abdicated, betrayed what I'd assumed were his principles, in order to be saved, by me, from me, and he'd got nothing by it. (61)

Not merely being betrayed by the former lover but also she believes that she is betrayed by her parents. In fact, her mother who always taught her to do the right things, not to torture animals, and to care about the nature was a symbol of strength for the narrator. The narrator recalls the incident of the bear which comes to their food tent for food. She says that she "stood up and walked towards it: it hesitated and grunted. She yelled a word at it . . and it turned around and thudded off into the forest(54).Getting ill, becoming pale, and having" bloodless and shrunken"(20) face, her mother starts not to hear what is said to her. However, the narrator has faith in her mother's recovering thinking that she is strong enough to overcome her illness. But, "when she died [she] was disappointed in her" (21).

Not to mention, the disappearance of father in a mysterious way in the remote island makes the narrator feel more alienated. She explains:

All at once I'm furious with him for vanishing like this, unresolved, leaving me with no answers to give them when they ask. If he was going to die he should have done it visibly, out in the open, so they could mark him with a stone and get it over with. (38) 
In fact, she is sorrowful because her father even does not have a grave. Perhaps, whenever she feels awful, she would like to visit her dad's tomb, cries and reveals her shame of her killing her own baby but unfortunately he has not one. Therefore, she is mad with both of her parents. She tells herself that:

I'm not mourning, I'm accusing them,_Why did you?_ They chose it, they had control over their death, they decided it was time to leave and they left, they set up this barrier. They didn't consider how I would feel, who would take care of me. I'm furious because they let it happen.(124-125)

Actually, her alienation starts in her childhood. Having atheist parents whereas other children have religious ones and speaking English in French territory Quebec are the other two reasons which make her feel alienated from the rest of the world. In addition to these two reasons, moving from one place to another due to her father's work when she was a child makes her more alienated for not having a strong relationship with other children. Furthermore, since she is a new student every year, the other children disturb her by tying her on a tree, tricking and torturing her. Hence, the narrator begs God "to be invisible" (49) in order not to get disturbed by children because "being socially retarded is like being mentally retarded, it arouses in others disgust and pity and the desire to torment and reform" (49). When the narrator realizes that she has not disappeared she thinks that the people have "the wrong God" (49).

What also contributes to the narrator's alienation is the social pressure casting the protagonist in a certain gender role. The impact of this pressure on the narrator is the total withdrawal from what surrounds her. As a matter of fact, learning gender roles starts early in the childhood period. "The brain is neutral . . what to feel was like what to wear, you watched the others and memorized it" (79). The narrator's opinion on gender reminds us of the notions of Judith Butler. For Butler:

There is no proper gender, a gender proper to one sex rather than another, which is in some sense that sex's cultural property there is no original or primary gender. . . but gender is a kind of imitation for which there is no original.(Butler 127)

Butler highlights that the inner identity is an illusion and the rules that control it work via repetition. The repeated signification of this fact can help destabilizing and demolishing this identity. The narrator always washes the dishes, dries the plates, weeds the garden, cleans the cabin and sweeps the floors. The protagonist learns to do chorus from her mother who always does the housework while dad goes out to discover about the plants. The protagonist also explains that is safer to say I want to be a "lady" or "mother" when I grow up because both of them are accepted by the society (Atwood 63).

Besides, the narrator casts a spotlight on the oppression which is imposed by school on students. When she looks at her school pictures, she notices that she is "in the stiff dresses"(77), the" colossal teachers[are] towering above"(77) them. What is more, at school "the right thing was to stare fixedly at the teacher as though at a movie screen (68). She goes on portraying school for us saying that the students are stuck to chairs and "in school you had to do what the rest were doing" (34).

In addition to what is mentioned above, the nameless protagonist finds men alienating because they treat women and the nature badly. For example, David forces Anna to wear make-up all the time, scorns her and even compels her to strip for his film Random Samples. Generally speaking, men whether they are American or Canadian humiliate women, make fun of them and destroy the nature by overhunting and over consuming.

In summation, different types of oppression make the protagonist powerless and alienated therefore she yearns to gain power. By wishing to eat magic beans and stopping to have birth control pills, the protagonist illustrates her desire to have power and control over her life.

\section{Schizophrenia}

According to the anti-psychiatry movement, schizophrenia is the outcome of the social and cultural situations (Cooper 125) whereas in the view of psychiatry world, schizophrenia is a psychotic disorder which has a big impact on the way of thinking, feeling and acting. The significant symptoms of this illness are losing the ability to distinguish between the reality and the imaginary, not showing emotional reactions to events, namely being unresponsive, being paranoiac and believing to be always watched by others, having hallucinations, having disorganized behaviour like not wearing according to the weather or neglecting the hygiene and experiencing a decrease in the functioning which leads to diminish the ability of the patient to perform the social roles as a student, lover or a mother or employee(Andrews 412-413). 
The symptoms of schizophrenia can be seen in the unnamed character of Surfacing. The first thing that she suffers is paranoia which refers to the mental disorder. The paranoia can become delusions when illogical thoughts become so fixed in the mind of the patient. She starts to have suspicion from everything, every behaviour and every movement. She thinks that the other people plot against her trying to hurt her. Moreover, nothing can persuade her that her suspicion is out of imagination.

When David tells her that her father is found and he is dead, she is unresponsive thinking that David says that because he wants to give her pain. Therefore, she states that "If he could invent, I could invent also, I've read murder mysteries" (Atwood 114). And when Joe and her friends are about to leave the island talking with Evans, she thinks that "they will be plotting, a strategy for recapture" (122). Later, when she sees hunters on the island, she thinks that they can hunt, kill and hang her just like heron on the tree. The protagonist suspects everyone around her even she cannot trust her lover who calls for her and hesitates to leave the island without her.

Hallucination is another symptom of schizophrenia. A patient can see illusions thinking they are real. The unnamed story- teller sees the visions of her mother on the island. She states that "then I see her. She is standing in front of the cabin." 133. Her mother wears her leather jacket. She feeds the jays. She looks at the protagonist through her as if she knows that something is there but she does not see. When the protagonist approaches her, all the birds fly. She starts to wonder which bird is her mother. Later, she sees the vision of her father near the cabin."He is standing there with his back to me, looking in at the garden"(136). He looks at the cabin. She believes that he is sorry for spoiling the nature by building a cabin among trees on the island.

Significantly, I think the nameless protagonist suffers clinical lycanthropy which denotes“ delusional conviction that one can be- or has been- transformed into an animal, and/or display of animal -like behaviour suggesting that conviction . . . In clinical practice, it tends to be diagnosed schizophrenia, bipolar disorder, or depression"(Blom 101). The protagonist is just like Bertha Mason in Charlotte Brontë's Jane Eyre. Berthais described as "strange wild animal" and inhumanely as "it". The protagonist of surfacing also sees herself as an animal with "eyes lightblue in dark red skin" (Atwood128) and her hair stands tangled out from her head. She turns the mirror backward to the wall. She says that "it is no longer traps me" (128). Since madness is a metaphor of the revolution against patriarchy world therefore she refuses to have fabricated self just like Anna who spends her day in front of the mirror using make-up to satisfy the expectation of the patriarchy realm. Then she starts to destroy everything in the cabin. In order to get rid of her past, she burns her scrapbooks, her ring, and the maps of father and photo albums. By burning her materials, she aims to eliminate the traces of the civilization and tries to open a new page in her life where there is no history. The process of burning is actually very important because it is a step to her treatment in the next period of life.

For the protagonist, being an animal is better than being a human because animals do not lie like humans. She behaves like an animal. She gets naked, eats raw vegetables and unwashed fruit, does not walk on the paths, lives in a den, uses a blanket, waits her fur to grow in order to make her warm, licks her scratches and cannot use or understand the language. Even she decides not to teach her child language. She refuses to use the language of the world because it is the language of lies and the language of oppression which makes the women subordinate, weak and indecisive.

Getting exhausted and falling asleep, she dreams that her parents are on the canoe, head away from the bay and go to the earth, water and air. They are out of reach. I think when her parents go away in the dream, they want her to be strong, to get rid of imaginary visions and take care of the baby in her womb. The message of the dream will help her to step to the rational realm and return to the civilized world. In other words, "she has successfully integrated her 'other half' by establishing coniunctio with her mother and father" (Misra 84).

\section{The Journey of Self-discovery}

The heroine of Surfacing starts her journey when she decides to come back to her village to look for her missing father. Then by staying alone on the remote island, she consolidates her will to explore what wrong is with her and why she cannot react or feel just like others. In the course of the journey, she starts to remember her alienated childhood and the causes of being isolated in the place where she lived, evaluate the relationship between Anna and David which depends on domination, and see how patriarchy powers destroy the nature. Diving into lake and seeing her drowned father, she has flashback of every disturbing event in her past life like the failed relationship with art professor, conceiving the real character of the ex-lover who is just an ordinary man and the aborted foetus. She gets insane and starts to behave like an animal. 
As a matter of fact, she knows that she has choices either staying in hospital or zoo in the city, leading life as an insane on the island or the other "alternative is death" (Atwood 139). If positive things do not take place in her life, then the "ultimate escape then is suicide which has the main appeal . . . that is offers oblivion"(Baumeister 90). Actually, the miracle comes true and she feels and anticipates that there is a living baby which is in the shape of a goldfish in her belly. Then she states "if I die it dies, if I starve it starves with me. It might be the first one, the first true human; it must be born, allowed" (139). Since "the rules are over"(137), therefore, she returns to her cabin, eats, dresses and turns the mirror. When she looks at the mirror, she sees only a natural woman. There is no wrong with her. The wrong is with the society that she lives. Having a baby in her womb, having Joe who comes to island to look for her, promising her parents "to prefer life"(137) and getting rid of her past memories can be four good reasons to make her powerful and helps her to " refuse to be a victim"(139) in the society.

The schizophrenic protagonist is not a mad woman who needs therapy and treatment in order to regain her sanity. Rather, she has to go through schizophrenic journey where "a spiritual death and rebirth" (Showalter 230) are achieved. The journey is like the voyage of an epic hero who sails to the underworld of the inner psychic. At the end of her journey, she reaches self-knowledge and the wholeness where the self is no longer spilt.

\section{Conclusion}

Not conforming to the normality of the society, the nameless character sets off a journey where she quests for truths, self-analysis and cleansing from her guilt. Right from the beginning, she gets subjected to the lies of men, she witnesses how the patriarchy always asserts not only his domination over the women but also on nature. What is more, she finds herself forced to help the patriarchy to commit a crime against the nature by killing the living entity in her womb. This crime leads her to suffer psychological trauma, alienation, isolation and schizophrenia with all symptoms of having paranoia, hallucination, and even showing animalistic behaviors. Her behaving like an animal shows her complete refusal to be a human who spoils everything around him. In addition to that, it illuminates the author's aim to create a protagonist who refuses to use the male-centered language which allows and encourages destructive relationships with the people and the nature. Additionally, the author wants to show how madness is painful and dark experience.

Rethinking of all experiences that she has gone through, she reaches to the conclusion that she will not give chance to anyone to take the power from her. She will not be the victim like Bertha in Jane Eyre who burns everything and even herself or like Esther in the Bell Jar who attempts suicide and is confined to the mental asylum. On the contrary, she decides to return to the city to continue from where she stopped but this time she is more confident of herself. In her self-discovery journey she arms herself with weapons of superior knowledge which will help her to fight and defend herself.

The madness in Surfacing is used as a metaphor for shedding light on the fact that the patriarch society produces insane women. Once women determine to gain their power, a "movement form disorder to order" (Wolfe and Wolfe 899), from insanity to sanity and from primitiveness to civilization can be seen.

\section{Works cited}

Alban, Gillian M.E. The Medusa Gaze in Contemporary Women's Fiction: Petrifying, Maternal and Redemption. Newcastle upon Tyne: Cambridge Scholars Publishing. 2017.

American Psychiatric Association. The Diagnostic and Statistical Manual of Mental Disorders. 4th ed., Washington, DC: APA Press, 2000. Dominick, Writing History, Writing Trauma. Baltimore: The Johns Hopkins University, 2001.

American Psychiatric Association. Report of the APA Task Force on Mental Health and Abortion. Washington, D.C.: Washington UP, 2008.

Andrews, Gwendolyn V. Review of Handbook of social functioning in schizophrenia. Psychiatric Rehabilitation Journal, vol. 24, no. 4, 2001, pp. 412-413. Atwood, Margaret. Surfacing. NewYork: Anchor UP, 1998.

Baumeister, Roy F. "Suicide as escape from self." Psychological Review, vol. 97, no. 1, 15 Jan.1990, pp. 90-113. Berthold-Bond, Daniel. Hegel's Theory of Madness. New York: Sunny Press, 1995.

Blom, Jan Dirk. A Dictionary of Hullicination. NewYork: Springer, 2010

Butler, Judith. Gender Trouble: Gender Trouble : Feminism and the Subversive of Identity, London: Routledge, 1990

Chesler, Phyllis. Women and Madness. 2nd ed. New York: Four Walls Eight Windows, 1997. 
Cooper,D. Psychiatry and Ant psychiatry. London: Tavistock, 1967.

Daronkolaee, E., Hojjat, N., \& Bakjtiari, M. "A Survey of Man's Alienation in Modern

World: Existential Reading of Sam Shepard's Buried Child and True West." Internationa Journal of Humanities and Social Science Vol.2, no.7, 2012, pp. 202- 209.

Feder, Lillian. Madness in Literature. Princeton, NJ: Princeton UP, 1980.

Foucault, Michel. Madness and Civilization. London: Tavistok, 1967.

Freud, Sigmund. "Mourning and Melancholia: The Standard Edition of the Complete Psychological Works of Sigmund Freud, (1914-1916)." On the History of the Psycho-Analytic Movement, Papers on Metapsychology and Other Works, vol. 14, 1917, pp. 237-258.

Herman, Judith. Trauma and Recovery. New York: Basic Books, 1992.

Marček, Tamara. Alienation, Isolation and Re-establishment of Identity in British Modernist Novels. MAThesis. University of J.J. Strossmayer in Osijek, 2016. Web: 26 April 2018.

Misra, RK."From Immersion to Emergence: A study of Atwood's Surfacing. Journal Humanities and Social Science, 2015,pp. 84.

Mollon, Phil. Freud and False Memory Syndrome. London: Icon Books, 2001.

Showalter, E. The Female Malady: Women, Madness and English Culture 1830-1980. London: Virago, 1987.

Wolfe, K. K. \& Wolfe, G. K. "Metaphor of Madness: Popular Psychological Narratives".Journal ofpopular Cultur, vol. 9, no. 4, Spring 1976, pp. 895-907. 